\title{
Highsmith's The Price of Salt: A Harbinger of Homosexuals' Happiness
}

\author{
Bhawana Pokharel, PhD
}

\begin{abstract}
Patricia Highsmith's The Price of Salt embodies homosexual relationship between its female characters namely Therese and Carole. In doing so, it presents a resistance to the contemporary heterosexual society which accepts only heterosexuality as its sexual norm. The article argues that the character's rejection of the traditional mode of heterosexual relationship is in order to search for their lesbian self though that is taken as a deviation in the society; and so it faces various challenges. However, the characters together overcome the obstacles laid down by the society and move forward to finding freedom as well as establishing a new path which is taken as an unconventional practice in the then society; in turn, it proves to be the harbinger of hope and happiness for their kind. To substantiate this claim, the article draws from Lillian Faderman, Adrienne Rich, Judith Butler and Helen Boyd for the different aspects of lesbianism and queer theory they present. Similarly, the article is a descriptive, interpretive and analytical reading of the novel on the basis of the ideas based on the above mentioned scholars.
\end{abstract}

Keywords: Deviation, heterosexuality, homosexuality, lesbianism, queer theory.

\section{Introduction}

The Price of Salt by Patricia Highsmith was first published in 1952; and was received as the novel of love society forbids. It is a saga of emotional and physical obsession towards the same sex that was considered inappropriate in the society. The book features two main characters i.e. Carol and Therese. Other characters get introduced as the plot unfolds. But the story mainly focuses on these two women's deep feeling, subtle expression, and candid celebration of homosexual attraction which becomes the core cause of happiness in their life.

The homosexual relationship between its female characters namely Therese and Carole presents/depicts the resistance to the contemporary heterosexual society which accepts only heterosexuality as its sexual norm. The objective of the article is to argue that the character's rejection of the traditional mode of heterosexual relationship was in order to search for their lesbian self though that was taken as a deviation in the society and so it faced various challenges. The rationale of the article is to identify and reiterate the implied message of the author that if the people in real life alike the characters, together overcome the obstacles laid 
down by the society and move forward to finding freedom as well as establishing a new path which was taken as an unconventional practice in the then society, it will bring hope and happiness for their kind at present, too. Lillian Faderman, Adrienne Rich, Judith Butler and Helen Boyd who present different aspects of lesbianism and queer theory also support this rationale. Though the article is a descriptive, interpretive and analytical reading of the novel on the basis of the ideas based on the above mentioned scholars, it does not take into account any other issues or perspectives that the novel might portray.

The most significant aspect portrayed by the novel is that it does not focus on only their sexual behavior or social demarcation of it but its main thrust is their attraction at psychic and physical levels along with but before and above sexual intimacy. Sexual intimacy is one of the many things they share; however, the focus is on their emotional, material and inter-personal levels of camaraderie.

\section{Review of Literature}

Critics have perceived and evaluated different aspects of the novel. Charles Lyons claims that the art of Highsmith's writing is not persuasive because of impermeable layers of detailed ordinariness (12). Similarly, Victoria Hesford remarks that Carol's house, in The Price of Salt, becomes a hollow monument to middle-class hetero-normativity. The size and impressiveness of the house is remarked on by Therese, the younger woman Carol meets in the city when she first comes to visit (226). Likewise, Bonnie Mann delineates that Patricia's The Price of Salt reveals the postmodern issue regarding lesbianism. This is a new issue that obviously breaks the orthodox belief regarding sexual freedom. (18-19). As these critics point, Highsmith's writing is not compelling but suggestive. Carol's house, the representation of middle-class hetero-normativity is implied fulfillment after Therese, a homosexual, visits it. This issue of homosexuality was new in the then American society; it is also a postmodern issue of challenging the set up of heterosexual gender roles. Though these critics point out these main features, they do not articulate that it is indeed a celebration of lesbianism in different forms and layers of a life.

The inspiration behind this publication, as explained by Highsmith, was a woman she met in brief. Highsmith, then a 27 year old Bloomingdale employee, sold a doll to Kathleen Senn, a beautiful blonde lady. Despite the fact that the encounter was brief, Highsmith could not forget the lady. Soon after Highsmith got sick with chickenpox and in her bedridden state, the plot details of this novel played out in her mind. Highsmith retained Senn's credit card details and soon began spying on her. So the novel somehow reflects Highsmith's personal life when she was a young lady. 


\section{The Price of Salt as a Lesbian Narrative}

The novel starts when Carol walks into a store where Therese, then nineteen years old, was working over Christmas. The writer describes Therese as a lonely young woman who had just moved to Manhattan, New York to pursue being a theatre set designer, the career of her dreams. The plot in the novel revolves around these two main characters. After meeting in the departmental store, Therese gets Carol's address for shipping reasons and follows her impulse; she sends her a card. Carol responds and the two start spending time together. Carol gets described as "lonely" woman in the novel because she got entangled in a divorce process with her husband Harge (Highsmith 42). We also have the glimpse of Therese's love life. She is going out with Richard despite the fact that she feels neither love nor attraction for him as depicted in the text. She was never truly interested in any of the myriad of boys and men who showed interest. When Richard asks why she likes Carol, she says: "I like being with her, I like talking with her." She recalls the lines of a letter she had written to Carol and wishes to tell it to Richard in response to his question: "I feel I stand in a desert with my hands outstretched, and you are raining down upon me" (85-86). Therese prefers spending time with Carol; and, over time, she realizes that Carol appeals to her. Therese's attraction to Carol keeps growing, and she develops a strong feeling of love and care for her.

Richard, Therese's husband somewhat senses this; but simply "brushes it off" as a schoolgirl crush (Highsmith 86). Harge, Carol's husband, gets suspicious of the relationship between the two ladies when he meets Therese at Carol's house briefly. His suspicions arose because of the previous knowledge he had regarding Carol's homosexual relationship with her friend, Abby. Harge later takes their daughter Rindy (Carol's and Harge's), to live at his place, far away from Carol (103). Later, Carol and Therese had to part as Carol had to struggle to gain the custody of her daughter. However, in the end things settle as per their wish and Therese is shown joyfully advancing to Carol, which implicates lesbian liberty and happiness in the hetero-sexual world.

Highsmith is the prominent author who produced numbers of lesbian pulp fiction. Her choice of deviant and sometimes even shocking subject matter is one of the most controversial choices of the author. Though she is adept in choosing scandalous subject matter in her novels, her chief purpose is not to sensationalize the public sentiments. Through this means, she likes to foster the rights of the excluded and marginalized groups of women. In this regard, it is fair to say that she is a radical and progressive author.

\section{Lesbianism}

In order to deconstruct conventional notions residing gender and sexuality and other associated conventional concept including love, marriage and (sexual) morality, and to interpret the novel from lesbian perspective, this article makes use of lesbianism as a primary critical 
apparatus.

Lesbian is defined as a female-female sexual-orientation or behavior or homosexual relationship between women. In other words, romantic and erotic attraction of female is considered as lesbian. It also refers to the condition in which a woman identifies herself as a lesbian. Lesbianism is also a tendency, principle and the way lesbian is advocated and supported. Some women who engage in homosexual behavior may reject the lesbian identity entirely, refusing to identify themselves as lesbian or bisexual.

Lillian Faderman defines lesbianism in an overview, placing herself midway between the exclusive and inclusive approaches to lesbianism, she claims:

Lesbian describes a relationship in which two women's strongest emotion and affections are directed towards each other. Sexual contact may be part of the relationship to a greater or lesser degree, or it may be entirely absent. By preference the two women spend most of their time together and share most aspects of their lives with each other. (17-18)

Surprising it might be, but according to Faderman, the women who have lesbian tendency show emotional inclination towards each other for the relationship. In their relationship, too, sexual orientation may or may not take place; they can share other aspects such as emotional, psychological, and social and may spend most of their time together as partners.

Moreover, the term transgender is used to critique the heterosexual marginalization of homosexual and bi-sexual activities. Chris Beasley explains the practice of transgendering as "transgender refers to people adopting a sexed identity different from their assignment at birth" (52). The lines presuppose that certain gender roles are assigned to every individual at the time of birth. But if one goes beyond the boundary of this gender identity (man or woman), it is the practice of "transgendering." A lesbian, in this context, does not fall under either of the category: masculine and feminine. Judith Butler writes on this issue as follows:

Indeed, a lesbian . . . transcends the binary opposition between woman and man; a lesbian is neither a woman nor man. But further a lesbian has no sex; she is beyond the categories of sex ... Indeed, the lesbian appears to be third gender, as I shall show, a category that radically problematizes both sex and gender as stable political categories of description. (Gender 144)

Butler ascertains that lesbianism in practice is embedded in trans-politics, especially transgendering and transexuality. To be a lesbian is surely to go beyond the discourse of sexuality. Moreover, having homosexual relation is the practice that makes the category menwomen more problematic. In this sense, lesbian crosses this limit; they are neither men nor 
women since the position between men and women sees the heterosexuality the only option in normal discourse. Here in this situation there is a remark of Catherine Beasley which seems relevant: "It used to distinguish those who wish to alter their gender a permanent but less literal sense, that is, those who live as the opposite gender or as ambiguous gender" (160). He means to say that gender is not permanent because it depends on the preference of the people's desire. Some people are born as a boy; but they enjoy living like a girl and vice-versa.

In Heterosexual Plots and Lesbian Narratives, the butch female (masculine and feminine) relation is described as a constellation which denies male and female gender categorization for instance by disrupting the boundaries of traditional clothing (Farewell 12). The genderless condition of the narrator is supported by butch-famine dynamics:

The titles "butch" and "femme" are most commonly assumed to be labels used in the lesbian community to distinguish the more masculine partner in a relationship from the more feminine partner. In reality, there is a lot more to it than that being a butch doesn't only mean tough or strong, and it definitely does not mean in control in relationships. (23)

Lesbian community believes that sex is not only determined only by physical body. Rather an individual's own sexual inclination as well as experience establish and prove her identity:

Being a femme also does not mean feminine all the time and it definitely does not mean powerless. It is not about power; it is not about one partner being the "man" and one being the woman in the stereotypical heterosexual sense. But it is an amazing dynamic where two people who are at opposite ends of the spectrum balance each other out perfectly. (23)

The butch-female dynamics in lesbianism plays a vital role as there is not equal relationship and equal power between two partners. Between the two, the radical partner assumes the role of butch and takes other as femme.

Steven Seidman mentions that sexuality is untouched area in human history which is taken as a separated issue by creating a lot of discrimination in women relation. She opines:

However, there is one aspect of human life that has resisted disenchantment: sexuality. Until recently, sociologists have viewed sexuality as a part of nature. They have shared with popular opinion the view that sexuality is biologically structured into the human species and obeys natural laws. (1-2)

Seidman pinpoints that sexuality is perhaps the last human dimension that many of us refuse to grant is socially created, historically variable and therefore deeply political. However, this is changing. 
According to Adrienne Rich, this orthodox perspective always brings the biasness to accept the unusual relation like homosexuality in the society which needs to be deconstructed to give the identity and power for all people. She further argues:

I have learnt more from some of those books than from others; but on this I am clear: each one might have been more accurate, more powerful, more truly a force for change, had the author felt impelled to deal with lesbian existence as a reality, and as a source of knowledge, and power available to women; or with the institution of heterosexuality itself as a beachhead of male dominance. (13)

Further Rich opines that lesbian existence is the bedrock to deconstruct the Western thought regarding sexuality. The Western metaphysics isolated the homosexuality implementing the demarcation of orthodox religion. But the lesbian freedom has been a source of knowledge and power for lesbians to introduce themselves as equal as common people who practice heterosexuality.

\section{The Price of Salt as a New Notion of Sexuality}

The very title of the novel used by Highsmith grabs readers' attention. It is symbolic and significant in dealing with the subject as of lesbianism. It evokes the meaning of sacrifice of Carol and Therese for their identity and freedom. From the very beginning of the novel to the end the characters' behavior to each other is depicted as a challenge to the then society that conceived only heterosexuality as a normal sexual orientation. To dismantle this notion, Highsmith very subtly, smoothly and softly dramatizes female-female attraction, affection and affiliation in its most vivid form through Therese Carol relationship.

Carol comes as her first customer to buy a doll and she asks Therese, who was a newly appointed sales girl for the Christmas rush: "Do you have the dolls that wet?" (Highsmith 5). They felt attracted to each other when "their eyes met at the same instant" (18). Therese was glancing up from a box she was opening: "The woman was looking at Therese too, with a preoccupied expression as if half her mind were on whatever it was she meant to buy here, and though there were a number of sales girls between them, Therese felt sure the woman would come to her" (18). She came, bought the things and when was about to pay the bills, she came close. Therese was dazed due to the smell of her perfume and she wished the woman asked her for seeing again: “Are you really so glad to have met me? Then why can't we see each other again? Why can't we even have lunch together today? Her voice was so casual and she might have said it so easily" (19). Therese sends Carol a Christmas card which urges her to see her next.

This time they met at a restaurant; Carol offers Therese a cigarette. When Therese leaned toward the lighter "the woman was holding for her, towards the slim hand with the oval red 
nails" (23). The "slim hand" and "oval red nails" attract Therese to Carol. If we take Therese's sending her a card as her care, we can take this as an ignition of bodily attraction between them. Carol shows her liking of Therese when she acknowledges her effort in sending the card and hints that their relation should grow over time: "I like this!" "What?" Therese asked. I like that someone sent me a card, someone I did not know, it's the way things should be at Christmas. And this year I like it especially." ... . "You are a pretty girl" (24). It was not that only Carol admired Therese but Therese too adored Carol as Highsmith writes: "when Carol laughed, putting her head back, it was a sound more beautiful than music" (24). The pleasantness of their camaraderie and intensity of their attraction is implied through the pleasant and appealing aroma of Carol's perfume:

[T]he dusky and faintly sweet smell of her perfume came to Therese again, a smell suggestive of dark-green silk, that was hers alone, like the smell of a special flower. Therese leaned closer toward it, looking down at her glass. She wanted to thrust the table aside and spring into her arms. (Highsmith 25)

The lines above demonstrate Therese's mounting attraction to Carol. She wished there were no material object between them i.e. the table and she could dive into her arms. They grow fond of each other so keep searching for opportunities when they can be together: "What do you do on Sundays. "I don't always know. Nothing in particular, what do you do? Nothing-lately. If you'd like to visit me sometime, you're welcome to" (25). Therese understands Carol without her telling things verbally and addresses Terese as "a strange girl flung out of space" (26). Her being perceptive of Therese's condition is juxtaposed with a male's being dismissive about her.

For the same reason, when Richard and Therese were walking the street, Therese was full of Carol in her mind: "it would be almost like love, what she felt for Carol, except that Carol was a woman. It was not quite insanity, but it was certainly blissful. A silly word, but how could she possibly be happier than she was now, and had been since Thursday?" (27). All the above descriptions are in line with Faderman's opinion that Lesbian describes a relationship in which two women's strongest emotion and affections are directed towards each other (17-18). In fact, it was a multi-level attraction - emotional, physical as well as sexual. It has been laid bare through Carol's relation to Richard who makes effort to woo her to the bed:

I wish we could share one together," Richard said.

"Share what?"

"Share a room!" Richard boomed out, laughing ... "Yes," she said. She was thinking of something else. If she stopped scrimping to save money for Europe ... (27)

Richard was not even on her mind when it comes to sexual intimacy and indulgence. Rather, she was thinking about a trip, away from him. She clarifies it to Richard that she does not love him but just likes him: "I am not in love with you," she said . . but I like you" (29). Therese 
was "miserable" and "ashamed" with her relation with Richard because in her experiences and words:

[I]t was so impossible and so embarrassing because she didn't want it. There was always that tremendous block of not even wanting to try it, which reduced it all to a kind of wretched embarrassment and nothing more, each time he asked her. She remembered the first night she had let him stay, and she writhed again inwardly. It had been anything but pleasant. (29)

Therese had no aptitude for hetero-sexual relationship. It was rather embarrassing for she did not want it. The first time when they had it was painful, not pleasant. Out of the experience, she gathers courage and rejects Richard's proposal of going to Europe: "No," Therese said, finding her voice at last. "I just can't tonight, and I can't go to Europe with you either. . . . because I don't want to sleep with you" (29).

Instead, she plans, decides and goes to see Carol for the second time, and then Carol invites her to go to her home: "Let's go to the house. It's pretty out there." When they headed toward Carol's home, "A wild, inexplicable excitement mounted in Therese as she stared through the windshield. . . She felt Carol glancing at her from time to time." (31). As they reach home and after having some food they engage in a talk during which Carol asks Therese:

"Do you meet a lot of people across the counter this way? ... . Well - do you meet many people this way?"

"No," Therese said.

"Not many? Just three or four?"

"Like you?" Therese met her eyes steadily.

And Carol looked fixedly at her." (33)

It reveals that Therese's had been a homosexual orientation and indulgence when it comes to attraction. As Faderman believes, "sexual contact may be part of the relationship to a greater or lesser degree"(17-18). In their relationship, it is present; however, comparatively at a lesser degree.

Though both of the characters i.e. Therese and Carole are lesbians, their likes, choices and practices are different. Therese though gets attracted to women (above her age in the novel) plays the weak or the submissive one and Carol the strong or the dominant, when it comes to partnership. In other words, Therese is the "femme" and Carol is the "butch" as discussed by Farewell in his conception of "butch" and "femme" within the two females' relationship, too (23). Carol plays the very well may be for the same reason Therese remains with Carol who came up behind her and set her hands on Therese's shoulders:

It seemed an age as her hands moved toward her neck and under her chin, an age of 
tumult so intense that it blotted out the pleasure of Carol's tipping her head back and kissing her lightly at the edge of her hair. Therese did not feel the kiss at all. ... "Slip your shoes off," Carol said softly, but in a tone that commanded obedience. (33)

Carol's hands are described as masculine, before implying that her behavior is also manly. Carol's kiss pleases her. Later, when Carol wants her to sleep in the bed, makes a command like expression which too shows that Carol enacts the butch. Not only in sensible and sexual matters, but also in small matters Therese shows her emotional dependence upon Carol:

"Shouldn't I leave?" Therese asked.

Carol looked at her in the same way she had when they first entered the house. "Not unless you want to. No. We'll take a driver later, if you want to." (37)

Therese is loved, handled and cared by Carol. She tells her to go only when she feels like doing. Not only she enjoys being with Carol but also expects and anticipates to see her often. As she was leaving, she asks: "Therese blurted suddenly, "Will I see you again? But there was not a moment when she did not see Carol in her mind, and all she saw" (39). Therese was in love with Carol in head and heart. They shared each other's secrets and sensitivities with a touch of care and empathy: "When they met in the foyer where they had met before she looked "depressed and it dampened Therese instantly" (41). One's sadness started to mean the other's. In this empathic bond, they took the privilege of discussing their sexual experiences with other men:

"Do you sleep with him?" Carol asked her.

"I did. Two or three times." Therese told her about those times, the first time and the three times afterward. She was not embarrassed talking about it. It had never seemed so dull and unimportant before. (43)

Therese narrates about her excruciating experience with Richard. She was very comfortable to share its dullness with Carol; as the former felt tedious whereas the latter was palpitating and fulfilling. For the same reason when Carol asks her about giving Richard a second chance, Therese states:

"Don't you believe in giving people another chance?"

"But why? It isn't pleasant, And I'm not in love with him."

"Don't you think you might be, if you got this worked out?"

"Is that the way people fall in love?" (43)

Therese says to Carol that she does not love Richard. And, love does not happen forcefully. Neither can we make it happen. She also confides that she was never in love with anybody before: "Were you ever in love, Therese? She waited, until the word from nowhere, false, guilty, moved her lips, "No." "But you'd like to be." Carol was smiling" (43). Carol comprehends Therese's inclinations and desires to be in love with her. They tend to take and 
treat their relationship as of love, not only of sex:

Is there a word? A friend, a companion, or may be just a sharer. What good are words? I mean, I think people often try to find through sex, things that are much easier to find in other ways. . . . I just like to be here with you," Therese said. (45)

Beyond and above sex, they want to establish a relation of caring and sharing. This portrayal reverberates Federman's idea about lesbianism that discussed above that by preference the two women spend most of their time together and share most aspects of their lives with each other, however there may be presence of sex or it may be completely absent (17-18). Carol and Therese have a bond in which they share all the aspects of their lives which they did not find comfortable to do with their male counterparts. Sharing full of care about the multiple aspects of life facilitates their sexual relationship as it brings the aura of familiarity between them: "It's Christmas," she said. "You would better stay the night" (45). Carol craves to have more and more night stays. On the other hand when Carol talks about Richard, Therese feels a kind of jealousy: "Carol liked Richard- which could only be her own fault- and a distant jealousy prickled her, sharp as a pin" (46). Therese wants Carol to be solely hers. Neither can she imagine sharing her with Richard nor with Abby:

When Abby comes to Carols and helps her in the kitchen Therese notices her, "Abby paid no further attention to her only took off her coat and started helping Carol with the coffee. Her waist and hips looked perfectly cylindrical, without any front or back under her purple knitted suit. Her hands were a little clumsy, Therese noticed, and her feet have none of the grace of Carol's. (47)

Therese, undergoes an internal self-inspection to find out if she also likes Abby. She realizes that Abby's being and body does not move her, it was only Carol's that does. She discovers that if she loves anyone it was Carol. When Richard asks Therese to make a wish, she "wished for Carol" (49). However, Therese, due to her being the product of the society that took only heterosexuality as its norm cannot be sure, therefore, asks: "It is possible for two women to fall in love with each other?" (53). She seeks for its answer within herself and finds out that "compared to her feelings for Carol, Therese says, her attraction to Richard was nothing, "but that was nothing, nothing like what she felt for Carol" (54). Carol proposed Therese for an over-night stay at her home: "we can spend the evening together." Therese at times notices Carol's body and admires it as "beautiful like a chord of music or a whole ballet" (57). All these feelings and perceptions suggest deep compassion as well as companionship between them which is the master key to a celebrative conjugal relation. They do not only celebrate compassion and companionship but also compromise for each other's likes and dislikes. Abby reveals to Therese that "Carol thinks a lot of her" (65). Therese, in turn, "wants to like Abby because Carol did" (68). As a couple, they want to take into account what nature has to offer 
them as human beings. They are ready to make any sacrifice to be together such as Therese would even "turn down a job on a ballet set to go away with Carol, to go with her through country he had never seen before, over rivers and mountains, not knowing where they would be when night came" (75). Their relation is based on the basis of most basic elements of human beings. Rather than any material pain and gain, they are happy to have a life of calm and composure.

Besides, care for each other is what they have to the optimum: "You have got circles under your eyes. Therese undressed quickly in the room with the twin beds. The phonograph in the other room played "Embraceable You" (75). They find one being embraceable to another, able to accommodate each other in the space they make for themselves. The space is lucid and graceful; it is care free and care laden: "Carol calls Therese with the expression "darling" (76). The other instant, Therese asks Carol if she can "kiss her good night?" Carol responds: "Why not? Anything seemed possible tonight" (77). Together they are able to create a context, space and time to cherish the unbound joy and peace they can cherish in each other's company.

Furthermore their relationship is not only of abstract level and abstraction. They show their responsibility with regard to finance. Carol who plays the 'butch' takes care of money matters. She gives two hundred dollars and speaks in confidence to Therese that it was for their tour, she needn't spend any of her money. Therese feels cared for. For their trip, Carol doesn't want Therese to spend her money and says that it "gives her pleasure" to spend on Therese (77). Same kind of yearning is shown to Carol by Therese when Richard asks her "why does she like Carol so much?" when she breaks a date with Richard on a slim chance Carol would come by. She says:

I like being with her, I like talking with her. I'm fond of anybody I can talk to. The phrases of some letter she had written to Carol and never mailed drifted across her mind as if to answer Richard. I feel I stand in a desert with my hands outstretched, and you are raining down upon me. (85)

Therese confesses that she is fond of Carol. Carol fulfills her. This fulfillment is compared with the replenishing rain when one gets dried up in a desert. Richard cannot believe about the candidness of Carol-Therese relation. So he doubts that Therese is in a "daze" (86). However, Therese confirms that she was not in a day dream or a trance but very much in sense.

Therese's inclination towards Carol is her endeavor to abandon heterosexuality, seen in light with what Jane Freedman conceives: ". . . the ways in which heterosexuality involves men's domination of women implies that the only true liberation for women will come through an abandonment of heterosexuality ..." (61). Heterosexuality permits male domination over women, therefore, some feminist think that if women carve for liberation in its true sense, they should avoid it. The same message is imbedded in Richard-Therese as well as Carol-Harge 
relationship.

Richard's evaluative and judgmental expression is juxtaposed with Carol's non-evaluative accommodation of Therese: "Because I just think of you as you, Sui generis" (99). This acceptance of a person as a person is what should found a human's relation. Due to this endorsement, their relationship shares the most compatible and core value they want to create for their comfort and carry on for their own core and care:

Darling, I forgot my towel, I think it's on a chair. Therese got it and took it to her, and in her nervousness as she put the towel into Carol's outstretched hand her eyes dropped from Carol's face to her bare breasts and down, and she saw quick surprise in Carol's glance as she turned around. Therese closed her eyes tight and walked slowly towards the bed, seeing before her closed lids the image of Carol's naked body. (102)

Carol and Therese celebrate their being and body. Going against all the heterosexual norms, they lead a homosexual life: "They spent a long evening and the night in a town called Defiance" (103). They disobey, deny and defy the then societal norms by knowing themselves and knowing what they are doing and taking pride over it. Therese admires Carol and touches her forehead with her fingers, at the hairline where she had kissed her that day (104). The desire in her to sleep with Carol in "the same bed overwhelms her" and she asks "can I sleep with you?" (106). Their defiance ranges from personal, social to psychological and sexual. They cherish sexual relation:

Then Carol slipped her arm under her neck, and all the length of their bodies touched, fitting as if something had prearranged it. Happiness was like a green vine spreading though her, stretching fine tendrils, bearing flowers through her flesh. She had the vision of a pale-white flower, shimmering as is seen in darkness, or through water. Why do people talk of heaven, she wondered. (107)

The sexual relation they have heals them of the pain of being marginalized and not properly understood by the rigid people who take only commend heterosexual relationship as normalcy. In the following morning too, they commemorate sex:

Carol's fingers tightened in her hair, Carol kissed her on the lips and pleasure leaped in Therese again as if it were only a continuation of the moment when Carol had slipped her arm under her neck last night. I love you, Therese wanted to say again, and then the words were erased by the tingling and terrifying pleasure that spread in waves from Carol's lips over her neck, her shoulders, that rushed suddenly, the length of her body. Her arms were tight round Carol, and she was conscious of Carol and nothing else of Carol's hand that slid along the ribs. Carol's hair that brushed her bare breasts and then her body too seemed to vanish in widening circles that leaped further and further. (107) 
The sexual bond and experience they share do not devastate but elevate them. It helps them gain the divine form of tranquility in which Therese goes oblivious of everybody and thing except for Carol. Love may be a form of divine, irrespective of sex and gender:

It was carol she loved and would always love. Oh, in a different way now, because she was a different person, and it was like meeting Carol all over again, but it was still Carol and no one else. It would be Carol, in a thousand cities, a thousand houses, in foreign lands where they would go together, in heaven and in hell . . before her arm lifted suddenly, her hand waved a quick, eager greeting that Therese had never seen before, Therese walked towards her. (166)

Carol and Therese's love is not the form of love that does not suggests sensuality; but it is the kind of love in which one finds coherence, congeniality, contentment and compliance.

They strongly fight against western thought presenting sexual relation and phenomena to claim that homosexuality is the part of a society. The stereotypical thought hegemonizes homosexuality as anatomical; therefore, Carol and Therese sacrifice love, marriage, family and children for the sake of personal discovery and identity. Highsmith's treatment of the theme reveals that she puts lesbianism or homosexuality above all other kinds of sexual orientations. However, she is not exclusive of a hetero-sexual orientation; she is all inclusive and acknowledging:

The music lived, but the world was dead. And the song would die one day, she thought, but how would the world come back? She felt shy with him, yet somehow close, closeness charged with something she had never felt with Richard. Something suspenseful, that she enjoyed. A little salt, she thought. (44)

Highsmith does not degrade the attraction between male and female. Though little, its existence is not obliterated; she values both the relationships. However, she regards the passion between two females as "a little salt" i.e. something that is little more spicy or fulfilling.

Hence, salt undoubtedly seems to be something of value and something that matters. It is perhaps, suggestive of the fact that for a lesbian, another lesbian partner is a fundamental need to be happy. Exactly, to evoke the "price" of something invariably brings up a feeling of loss, a sense of something that is to be given up for something else to be gained. In this respect, the term "price" hints at the sacrifice they did for the sake of salt i.e. the price they paid for their joy.

One also may question, "Is the price of salt Carole losing Rindy?" Or is the price of salt simply emblematic of love in general that you cannot love truly without pain, without some sort of sacrifice? This is captured in the novel when the writer explores Therese's feelings towards Carol: 
Was it love or not that she felt for Carol? How absurd was it that she did not even know. She had heard about girls falling in love and, she knew what kind of people they were and what they looked like. Neither she nor Carol looked like that. Yet the way she felt about Carol passed all the tests for love and fitted all the descriptions. (54)

Carol engages herself in multiple relationships, but Therese is her match. There is no age limit and gender limit to her. Therese is young, but Carol is a mature woman. Carol involves in bisexual relation several times. She enlists many of her boyfriends as well as girlfriends. Carol challenges not only the heterosexual relationship but also the morality set by the western society. Carol's masculine character is contradicted with her social feminine character. Therese is also presented as rebellious.

In this way, The Price of Salt blurs the strict boundary between male and female and presents 'inbetweenness' of the female characters. Here, gender is determined not by biological criteria but by performance. The activities and performances of Carol and Therese go beyond the identification of any of the parameter set to determine gender. Highsmith, in this novel, dismantles the hegemonic perception of heterosexuality and very subtly, smoothly and softly dramatizes female-female attraction, affection and affiliation in its most vivid form through Therese-Carol relationship.

\section{The Price of Salt as Homosexuals' Happiness}

The Price of Salt is a lesbian novel that subverts the existing concept of equality and gender created by hetero-patriarchal discourse. It discards the idea that heterosexual relationship is the absolute and universal; and provides other possibilities. Moreover, socially queer, odd or deviant and restricted behaviors like homo-sexuality, trans-sexuality and bi-sexuality are highlighted with a view of bringing them into mainstream discussion about sexuality particularly through the sexual inclination, orientation and behavior of the characters.

The characters violate traditional hetero-sexual division of gender and sexuality by remaining beyond gender and age: and keeping relationships to both males as well as females. Carol and Therese celebrate lesbian body in its true form rather than as defined by the society. Highlighting the queer and deviant activities of the central characters namely Therese and Carole, this paper discussed that Highsmith dismantles conventional concepts of gender and sexuality and dramatizes lesbian issues of homosexuality which were rejected by the then western thought.

To conclude, the central story of The Price of Salt is woven under the rubric of queer hematology in general and lesbian narratology in particular; it is evident as we deduce from the perception of Carol, Therese and Abby. Highsmith shows the strategic use of lesbian and bisexual relationship through these characters who reign as female narrators in the story. In the 
JODEM: Journal of Language and Literature, vol. 10, no. 1, issue 12, 2019/ 2076BS

novel, the homosexual relation among the characters, especially between the representative homosexual characters Therese and Carol, is revealed to be the herald of their happiness.

\section{Works Cited}

Belsey, Catherine, and Jane Moore, editors. The Feminist Reader: Essays in Gender and Politics of Literary Criticism. Palgrave Macmillan, 1989.

Butler, Judith. Bodies That Matter: On the Discursive Limits of Sex. Routledge, 1993.

---. Gender Trouble: Feminism and the Subversion of Identity. Routledge, 1990.

Faderman, Lillian. The Gay Revolution. Simon and Schuster, 2015.

Farewell, Marilyn. Heterosexual Plots and Lesbian Narratives. vol. 2, New York UP, 1996.

Freedman, Jane. Feminism: Concepts in the Social Sciences. Viva Books, 2002.

Hesford, Victoria. "Patriotic Perversions: Patricia Highsmith's Queer Vision of "Cold War America in The Price of Salt, TheBlunder, and Deep Water." Women Studies Quarterly, vol.33 issue $3 / 4,1950$, pp. 215-33.

Highsmith, Patricia. The Price of the Salt. Greenwood Press, 2012.

Lyons, Charles. The New Sensors: Movies and the Cultural Wars. Temple UP, 1997.

Mann, Bonnie. Sovereign Masculinity: Gender Lessons from the War on Terrors. Oxford UP, 2013.

Rich, Adrienne. "Compulsory Heterosexuality and Lesbian Existence." Journal of Women's History, 1980, vol. 15, no. 3, 1980, pp.11-48. Project Muse. DOI 10.1353/jowh. 2003.0079. 17 April 2019.

Seidman, Steven, editor. Introduction. Queer Throry/Sociology. Blackwell Publishers, 1996. 